Article

\title{
International Expansion of Social Enterprises as a Catalyst for Scaling up Social Impact across Borders
}

\author{
Ignacio Bretos*(D), Millán Díaz-Foncea and Carmen Marcuello \\ Department of Business Organization and Management, Faculty of Economics and Business, University of \\ Zaragoza, Paseo de la Gran Vía 2, 50005 Zaragoza, Spain; millan@unizar.es (M.D.-F.); cmarcue@unizar.es (C.M.) \\ * Correspondence: ibretos@unizar.es
}

Received: 1 April 2020; Accepted: 15 April 2020; Published: 17 April 2020

\begin{abstract}
Scaling social impact and solutions beyond the local context is argued to embody a key mechanism for social enterprises (SEs) to contribute to the achievement of the sustainable development goals (SDGs) and to generate welfare-enhancing systemic change. In light of this, this article explores the potential of SE international expansion as a catalyst for scaling social impact across borders. From our reading of the literature, we discern three major typologies of cross-border scaling: Control-based, altruism-based, and hybrid. Drawing on a multiple-case study of nine international SEs, we examine why and how SEs deploy these scaling strategies on an international scale; the challenges to maximize social impact across borders associated with each of the scaling strategies, and the resources and actions that SEs can mobilize to manage such challenges associated with international expansion. Contrary to conventional wisdom and mainstream theory depicting SEs as small-sized organizations that suffer from different limitations to expand beyond their traditional national boundaries, our findings illustrate how these organizations can successfully operate on an international scale and simultaneously generate financial, social, and environmental value.
\end{abstract}

Keywords: cooperatives; international expansion; organizational growth; scaling; social economy; social enterprise; social entrepreneurship; social impact; sustainable development

\section{Introduction}

Processes of expansion and scaling social impact are increasingly recognized to be at the heart of social entrepreneurship [1,2]. Following Desa and Koch [3], scaling social impact can be defined as the "process of expanding or adapting an organization's output to better match the magnitude of the social need or problem being tackled" (p. 148). As noted by Zhao and Han [4], the prior literature on scaling has made significant progress in describing the diverse scaling strategies deployed by social enterprises (SEs) and in discerning the drivers or inhibiting factors of scaling processes. Yet, little is known about why and how SEs apply different scaling strategies on an international scale, the challenges faced by SEs to maximize social impact when they engage in cross-border expansion, as well as how SEs can overcome such challenges and deploy international expansion as a catalyst for scaling social impact across borders.

This article aims to shed light on these issues, which are relevant at least for two reasons. Firstly, growing evidence suggests that international expansion of SEs is far from a marginal phenomenon [5-7]. For example, in a recent study on 300 of the largest co-ops and mutuals in the world from different sectors and countries, Bretos et al. [8] found that the vast majority of them operate across borders through different strategies, ranging from contractual typologies such as direct exports, franchising, and licensing, to equity typologies such as greenfield investments, joint ventures, and full acquisitions. What is more, international expansion is not only confined to a few large SEs. Smaller SEs and social ventures have been equally found to operate and serve beneficiaries beyond their traditional 
national boundaries [9]. They frequently achieve such global dimension by engaging in "bricolage activities" to reconfigure existing resources at hand in constraining institutional environments [3], and by deploying information and communication technologies to identify and exploit global social entrepreneurship opportunities, to access funding and resources, and to create social networks and entrepreneurial alliances to drive international growth [10-12]. As revealed by some recent studies, however, organizational growth and expansion processes do not automatically lead to scaled social impact $[13,14]$, and might even generate tensions and risks for the SE to fulfill its social mission and to promote stakeholder involvement in decision making $[4,15]$. Therefore, it is crucial to explore the challenges faced by SEs to scale their social impact when they engage in processes of international expansion.

Secondly, scaling social innovations and solutions beyond local contexts is argued to be a key mechanism for SEs to contribute to achieving the sustainable development goals (SDGs) [16-18]. The SDGs are seen as complex global challenges that need to be addressed through a plethora of mechanisms and solutions [19]. These include the development of solutions that bring together a local perspective focused on the specific local resources, issues, and challenges of each region, on the one hand, and a global perspective that conceives social innovations and approaches as solutions that can be scaled and applied in other contexts, on the other [20,21]. Following Lubberink [22], we posit that bridging across national and global scales involves a key task for SEs: To develop a solution or innovation that responds to a societal challenge and, then, to scale such social innovation across borders (see also $[23,24]$ ). Scaling social innovations is expected to stimulate the effect of SEs on a macro-level by reaching larger groups or communities, thus influencing the behavior of a broader range of actors, generating large-scale institutional change, and, in sum, contributing to the creation of compensatory or transformative social change [2,22]. Consequently, it is essential to explore the resources and actions that SEs can mobilize to manage the challenges associated with international expansion and, thus, scale social impact across borders.

To address our research questions, we draw on the insights from nine case studies of SEs that have adopted different cross-border expansion strategies, thus facing varied challenges and designing distinctive solutions to scale social impact. Being aware of the important national differences regarding the concept of social enterprise and the organizations that can be labeled with this term across the world, we adopt a broad and inclusive international approach that conceptualizes SEs as organizations that, regardless of their legal form, explicitly pursue social and/or environmental goals and involve different stakeholders in decision making, while also engaging in commercial activities to sustain their operations [25]. According to this approach, SEs can be seen as part of the wide range of actors that make up the social economy sector [26].

The article is divided into six sections. The next section provides a brief review of the literature about scaling social impact. The third section details the methods and data used. The fourth accounts for the main results of the research, and the final sections are devoted to discussion and conclusions.

\section{Literature Review}

An important line of enquiry on growth and scaling up of social impact in SEs has emerged in the last decade. Existing research has mainly focused on classifying and describing the forms or types of scaling strategies deployed by SEs [3,15,23,27-37], proposing a variety of classifications according to different criteria (for a review, see, e.g., Han and Shah [14]). In a landmark study, Lyon and Fernandez [32] identify a wide array of scaling alternatives available for SEs, which involve either maximizing the impact internally (through new activities and more sites) or growing beyond the confines of the organization (through social franchises, use of kite marks, training and networks). An important criterion is the type of social impact generated. The literature generally differentiates the types of scaled social impact along a spectrum ranging from depth-scaling to breadth-scaling. Depth-scaling modes include 'scaling deep' and 'scaling out', which aim to expand the number, type, and/or quality of services in order to enhance the impact on the same target beneficiaries. 
Breadth-scaling modes, meanwhile, include 'scaling up' and 'scaling across', which focus on affecting more people and covering larger geographic areas $[3,14,27]$.

Other relevant taxonomies have been proposed. For example, in a study of environmentally motivated SEs, Vickers and Lyon [35] distinguishes 'small and beautiful' green niches focused on deepening impact within the specific communities, 'green knowledge economy' ventures seeking to achieve a wider impact through the provision of knowledge-intensive services and advice to others, and 'green collar army' ventures that prioritize employment creation in labor-intensive sectors and activities. Nazarkina [33] differentiates 'sell-out growth' through which social entrepreneurs sell their firms to larger mainstream competitors, 'acquisitive growth' based on the organic expansion of the company, and 'hybrid growth' via the use of long-term contractual organizational arrangements. Another influential classification is proposed by Dees et al. [30], who posit that scaling social impact has three forms: Scaling an organization, replicating a program, and spreading a principle. From our reading of the literature, we discern three major typologies of scaling according to the degree of central control and resource commitment (in a similar way to other authors such as Dees et al. [30] and Sezgi and Mair [34]): Control-based, altruism-based, and hybrid scaling. This taxonomy aims to encompass the different scaling strategies identified in the SE literature, as well as to include recent forms of scaling such as cross-sector partnerships, which are missing in some prior classifications.

Control-based scaling relies on a considerable degree of central control and coordination, and generally requires the greatest investment of resources by the parent organization. Control-based scaling strategies, which basically include mergers, acquisitions, and greenfield investments, involve the parent organization creating branch structures in the form of company-owned stores, offices, or plants; that is, all units are legally part of the parent organization [31].

Altruism-based strategies involve a disseminating organization that makes its social innovation available by actively sharing information and/or providing technical assistance to one or more recipient organizations that seek to replicate the approach or model [31]. Altruist strategies rely on few resources, and there is little centralized control by the source organization over the replication of the social innovation by the adopter [34], which tends to use the shared information and knowledge as it deems appropriate. Hence, the source organization is not interested in owning and appropriating the value created using its approach, but rather in altruistically spreading its model, ideas, or tools to generate broader social impact; that is, the focus of these strategies "is on replication, diffusion by other actors, and adoption rather than organizational control" [27] (p. 5). Common mechanisms for the diffusion of knowledge and information in altruist strategies include open sourcing, training, and consultancy [32]. Open sourcing involves an organization that creates and shares resources, materials, and publications that guide and advise others on how to implement the social innovation. With a higher level of support, the disseminating organization provides formal training to others, generally through courses, workshops, or seminars, in order to teach how to replicate the social innovation. Consultancy, meanwhile, usually involves providing long-term expert advice on how to replicate the social venture or innovation [36].

Hybrid scaling strategies offer the broadest range of possibilities for SEs to grow and scale social impact. They rely on long-term contractual organizational arrangements in which both the parent organization and the partner organizations maintain their autonomy, although, at the very least, they usually imply a commitment of both parties to share information and pool some level of resources [33]. In hybrid strategies, the relationship between the parent organization and the partners can range from loose cooperation to strongly linked structures [31]. Hybrid strategies represent an intermediate solution in terms of resource commitment and control. In comparison to altruist strategies, hybrid modes allow the source organization to gain greater control over its adopters and the process of transfer of knowledge and information. However, hybrid strategies also require more resources and support from the source organization. In addition, hybrid strategies promote more varied impact increments, as they can scale social impact both directly, by reaching a larger number of users, and indirectly, in a process through which the partners of the alliance can induce each other to carry out new activities 
and processes aimed at increasing social value creation [34]. Common hybrid forms of scaling include social franchising and a variety of strategic alliances.

Social franchising is basically the application of a commercial franchising approach to achieve greater social impact, rather than profit [38]. This strategy "involves an organization (the social franchisor) allowing others (social franchisees) to offer its social solution using its brand name and operational processes in exchange for upfront and ongoing fees" [39] (p. 2). The most common forms of strategic alliances to scale social impact are joint ventures and cross-sector partnerships. A joint venture is an alliance formed by two or more independent entities that aims to achieve common objectives, and which implies the creation of a new entity, business activity, or project. Many SEs have been found to form joint ventures not only to scale social impact, but also to minimize risk by sharing investments and control [40]. Cross-sector partnerships have come to the forefront in the last two decades as a promising way to address sustainable development challenges [41]. These include public-private partnerships between public and not-for-profit organizations that are set up to address social concerns more effectively and to increase efficiency and quality in the provision of public services, partnerships between SEs and mainstream corporations to operate commercial activities while implementing a social mission, and multiple partnerships between organizations from the business, public, and civil society sectors [24,42].

As claimed by several authors $[4,13,43]$, the extant scholarly literature on social enterprise growth and social impact scaling is largely biased toward success stories, and, therefore, "the negative side, particularly the tensions and risks, in the scaling process is largely ignored" [4] (p. 16). Only a few studies have explored the limitations faced by SEs to grow and scale their social impact and the challenges experienced by these organizations when they engage in the process of scaling up their ventures $[4,13,15,37,43,44]$.

Davies et al. [44] uncovers a series of values-based, business model-based, and institutional barriers that distinctively hamper social enterprise growth. Similarly, Bretos et al. [8] argue that the process of expansion is much more complex in SEs than in for-profit companies because the former must balance complex elements associated with their ethical values and democratic functioning. Other studies have focused on the consequences of scaling for the sustainability of the social venture, revealing that growth might impose critical challenges to preserve democratic governance practices, imprinting of the founder's values and morals, and connections and identification with the community, thus potentially resulting in legitimacy deficits from stakeholders that might deem growth as a threat to the fulfillment of the social mission [4,15]. Indeed, some studies have illustrated how SE expansion and organizational growth is not always conductive to an increase of social impact $[13,14,37]$. For example, Datar et al. [13] builds upon the case of the microfinance industry to elucidate how SEs in this industry significantly expanded their operations and achieved greater size but failed to deliver on promises of scaled social impact. The authors ascribe this failure to the fact that some microfinance SEs prioritized professionalism and efficiency over social goals. In a recent study, Islam [43] also explores how scaling social impact can create negative, unintended consequences such as intensified competition among SEs for limited resources and the triggering of hostile behaviors from certain governments that consider that advocacy work of SEs to scale their social impact might challenge or put in question national social welfare policies.

There is, however, a dearth of research about why and how different scaling strategies are applied on an international scale, the challenges to scale social impact across borders associated with each of the scaling strategies, and how SEs can overcome them. The case studies presented below aim to advance our understanding of these issues. 


\section{Materials and Methods}

\subsection{Research Approach and Sample}

With a view to addressing the questions raised above, we adopted a multiple case study approach $[45,46]$. In comparison to single-case studies, multiple-case research is prone to generate more generalizable, accurate, and parsimonious theory [47]. Our sample is made up of nine SEs, which were selected on the basis of theoretical sampling. This involved choosing each case for theory-building reasons; that is, to illuminate the focal phenomenon and to extend the emergent theory of cross-border scaling of social impact [45]. Table 1 summarizes the main characteristics of the sampled SEs.

To select our sample, in the first stage, we collected publicly available data from sector experts and actors working in the social economy field. Key sources included the World Cooperative Monitor reports and other studies published by the International Co-operative Alliance, EURICSE (European Research Institute on Cooperative and Social Enterprises), and CIRIEC (International Centre of Research and Information on the Public, Social and Cooperative Economy). Our aim was to find SEs that had encountered social-business tensions during international expansion and had designed innovative solutions to tackle these tensions and scale social impact across borders. An initial list of 24 SEs potentially eligible for our sample was identified.

In the second stage, we selected nine high-profile, information-rich SEs. Three cases were sampled in each of the three scaling categories identified from our literature review: Control-based, altruism-based, and hybrid. To do this, we looked for relevant data concerning the international expansion process of each SE and matched them with the main characteristics of each scaling category. In the case of control-based scaling, we selected SEs that had largely grown organically through branches and subsidiaries. In the case of altruism-based scaling, we selected SEs that had chiefly deployed methods and mechanisms to disseminate their approach or social innovations in an altruistic way. In the case of hybrid scaling, we selected SEs that had significantly expanded through the formation of strategic alliances with other organizations. In the case of some SEs that have simultaneously deployed multiple strategies to scale social impact across borders, we focused on the strategy they use most prominently. For instance, Mondragon recently partnered with the North American United Steelworkers union in order to promote Mondragon-like industrial coops across the US and Canada. Only about 10 manufacturing companies are trying to adopt the Mondragon organizational approach and methods. At the same time, Mondragon controls 150 manufacturing subsidiaries abroad. Accordingly, this SE was sampled in the control-based scaling category.

The cases were also purposefully selected to offer sufficient cross-case variance and provide a wide range of perspectives regarding how to manage the challenges associated with international expansion and scaling social impact across borders. The goal was to enable extending the emergent theory to a broad range of SEs [47]. In this regard, we looked for SEs that notably differ in terms of organizational size, maturity, economic activity, and/or services offered to beneficiaries, country of origin, and degree of international presence (i.e., number of countries in which the SE operates). We also prioritized the selection of SEs that had addressed similar international expansion challenges through the adoption of substantially different strategies. Lastly, in order to ensure theoretical saturation [46], we additionally analyzed three of the cases discarded from the initial list-each one corresponding to a scaling typology. This analysis did not add any significant, novel insights into cross-border scaling of social impact. 
Table 1. Case descriptions.

\begin{tabular}{|c|c|c|c|c|c|c|c|c|}
\hline Case & Headquarters & Year of Establishment & Main Activity & Social Mission Statement/Ethos & Main Scaling Strategy & Size & International Presence & Webpage \\
\hline Up Group & France & 1964 & $\begin{array}{l}\text { Development of payment methods } \\
\text { and management solutions for } \\
\text { companies and other social actors }\end{array}$ & $\begin{array}{l}\text { The Up Group combines economic development, } \\
\text { social innovation, and respect for the environment. } \\
\text { Its mission is twofold: to contribute to social progress } \\
\text { and to provide solutions for a better daily life. }\end{array}$ & Control-based & 3600 workers & $\begin{array}{l}\text { Operations and sales in } \\
19 \text { countries }\end{array}$ & https://up.coop/ \\
\hline Arla Foods & Denmark & 2000 & $\begin{array}{l}\text { Production and distribution of } \\
\text { dairy products }\end{array}$ & $\begin{array}{l}\text { Creating the future of dairy to bring health and } \\
\text { inspiration to the world, addressing ethical and } \\
\text { quality matters in a sustainable and responsible } \\
\text { manner to safeguard the company's reputation, } \\
\text { profitability, and growth. }\end{array}$ & Control-based & $\begin{array}{c}10,500 \\
\text { farmer-owners }\end{array}$ & $\begin{array}{l}\text { Operations in } 12 \\
\text { countries and sales } \\
\text { in } 105\end{array}$ & $\begin{array}{l}\text { https://www. } \\
\text { arlafoods.es/ }\end{array}$ \\
\hline $\begin{array}{l}\text { Mondragon } \\
\text { Group } \\
\text { (Industrial } \\
\text { Division) }\end{array}$ & Spain & 1956 & $\begin{array}{l}\text { Industrial activities (e.g., } \\
\text { household appliances, machine } \\
\text { tooling, automotive components, } \\
\text { etc.) }\end{array}$ & $\begin{array}{l}\text { Mondragon's mission combines the core goals of a } \\
\text { business organization competing in international } \\
\text { markets with the use of democratic methods in its } \\
\text { business organization, the creation of jobs, the human } \\
\text { and professional development of its workers, and a } \\
\text { pledge to development with its social environment. }\end{array}$ & Control-based & 40,000 workers & $\begin{array}{l}\text { Operations in } 97 \\
\text { countries and sales in } \\
\quad \text { over } 150\end{array}$ & $\begin{array}{l}\text { https://www. } \\
\text { mondragon- } \\
\text { corporation. } \\
\text { com/ }\end{array}$ \\
\hline $\begin{array}{l}\text { Hippocampus } \\
\text { Learning } \\
\text { Centres (HLC) }\end{array}$ & India & 2010 & $\begin{array}{l}\text { Provision of integrated and } \\
\text { comprehensive preschool and } \\
\text { primary grade education programs }\end{array}$ & $\begin{array}{l}\text { To provide quality and affordable education } \\
\text { opportunities for the children of } \\
\text { under-served communities. }\end{array}$ & Altruism-based & 700 teachers & $\begin{array}{l}\text { Centers in } 2 \text { countries } \\
\text { and several Indian } \\
\text { regions }\end{array}$ & $\begin{array}{l}\text { https://hlc. } \\
\text { hippocampus. } \\
\text { in/ }\end{array}$ \\
\hline $\begin{array}{l}\text { The Freecycle } \\
\text { Network }\end{array}$ & $\begin{array}{l}\text { United } \\
\text { States }\end{array}$ & 2003 & $\begin{array}{l}\text { Exchange and gift of free items for } \\
\text { reuse or recycling }\end{array}$ & $\begin{array}{l}\text { To build a worldwide gifting movement that reduces } \\
\text { waste, saves precious resources, and eases the burden } \\
\text { on landfills, while enabling members to benefit from } \\
\text { the strength of a larger community. }\end{array}$ & Altruism-based & $\begin{array}{l}9.2 \text { million } \\
\text { user-members }\end{array}$ & $\begin{array}{l}\text { Freecycle groups in } 139 \\
\text { countries }\end{array}$ & $\begin{array}{l}\text { https://www. } \\
\text { freecycle.org/ }\end{array}$ \\
\hline $\begin{array}{l}\text { Aravind Eye } \\
\text { Care System }\end{array}$ & India & 1976 & $\begin{array}{l}\text { Eye care-related activities (e.g., eye } \\
\text { surgery, research, production of } \\
\text { ophthalmic products, etc.) }\end{array}$ & $\begin{array}{l}\text { To eliminate needless blindness through } \\
\text { compassionate and quality eye care affordable to all. }\end{array}$ & Altruism-based & 5100 employees & $\begin{array}{l}\text { Model replicated in } \\
\text { hospitals in } 30 \text { countries }\end{array}$ & $\begin{array}{l}\text { https: } \\
\text { //aravind.org/ }\end{array}$ \\
\hline The Impact Hub & $\begin{array}{l}\text { United } \\
\text { Kingdom }\end{array}$ & 2005 & $\begin{array}{l}\text { Creation of business incubators } \\
\text { and co-working spaces for social } \\
\text { businesses }\end{array}$ & $\begin{array}{l}\text { To support enterprising initiatives for a better world } \\
\text { by growing a locally rooted, globally connected } \\
\text { community for measurable positive impact. It seeks } \\
\text { to inspire, connect, and enable people to take } \\
\text { entrepreneurial action in order to pioneer a just and } \\
\text { sustainable world where business and profit are used } \\
\text { in service of people and planet. }\end{array}$ & Hybrid & $\begin{array}{c}16,500 \\
\text { user-members }\end{array}$ & $\begin{array}{l}\text { Impact Hubs in } \\
55 \text { countries }\end{array}$ & $\begin{array}{c}\text { https:// } \\
\text { impacthub.net/ }\end{array}$ \\
\hline Ben \& Jerry's & $\begin{array}{l}\text { United } \\
\text { States }\end{array}$ & 1978 & $\begin{array}{l}\text { Production and distribution of ice } \\
\text { cream, frozen yogurt, and sorbet }\end{array}$ & $\begin{array}{l}\text { To operate the Company in a way that actively } \\
\text { recognizes the central role that business plays in } \\
\text { society by initiating innovative ways to improve the } \\
\text { quality of life locally, nationally, and internationally. } \\
\text { Their social mission compels them to use the } \\
\text { Company in innovative ways to make the world a } \\
\text { better place. }\end{array}$ & Hybrid & 800 employees & $\begin{array}{l}\text { Operations in } 4 \\
\text { countries and sales in } \\
38 \text { countries }\end{array}$ & $\begin{array}{l}\text { https://www. } \\
\text { benjerry.com/ }\end{array}$ \\
\hline $\begin{array}{l}\text { Join Us to } \\
\text { Maximize our } \\
\text { Potential } \\
\text { (JUMP) }\end{array}$ & $\begin{array}{l}\text { South } \\
\text { Korea }\end{array}$ & 2011 & $\begin{array}{l}\text { Provision of high-quality } \\
\text { educational services to children at } \\
\text { the bottom of the pyramid }\end{array}$ & $\begin{array}{c}\text { To create a society in which everyone can enjoy } \\
\text { learning opportunities and can grow without } \\
\text { discrimination. }\end{array}$ & Hybrid & 600 employees & Projects in 5 countries & $\begin{array}{l}\text { http://jumpsp. } \\
\text { org/en/ }\end{array}$ \\
\hline
\end{tabular}




\subsection{Data Sources and Analysis}

Data collection was conducted during 2019. Our research relied on data and information published by the companies from different sources such as annual reports, strategy plans, sustainability reports, company newsletters and magazines, corporate videos, and communications to stakeholders. In addition, we also drew on secondary empirical material retrieved from press releases, published interviews, as well as research articles and books. Secondary analysis of qualitative data involves the use of existing data to find answers to research questions that differ from the questions asked in the original research [48] and is based on the assumption that "engagement and interrogation of existing empirical work can be at least as illuminating and challenging as undertaking new studies" [49] (p. 606). This method is highly valuable for exploring sensitive issues with populations that are elusive or to which access is difficult [50], as was our case. Most of the SEs studied are headquartered outside of the researchers' country of origin. What is more, multinational SEs have been portrayed as "opaque black boxes" [51] (p. 438), in which their members are often reluctant to discuss the dilemmas and internal tensions arising from international expansion with external researchers with whom they do not maintain a close relationship of reciprocity and trust.

The study's data were transposed into a computer file for the conduct of data analysis. No computer-aided software was used. Instead, we performed a qualitative form of content analysis in which the sentence was the basic unit of analysis related by key words grouped as categories [46]. Given the scarce research in the area, content analysis was based on an inductive approach whereby patterns and categories are allowed to flow from the raw data rather than through application of theory-driven constructs [47]. To analyze the data, we followed common prescriptions for multiple case-based research [45-47]. We began by synthesizing the data for each firm into individual case histories in order to perform within-case and cross-case analyses. We triangulated the data, emphasizing themes that were supported by different data sources. The case histories ranged in length from 25 to 35 pages and included full quotations, data tables, and event chronologies.

Within-case analysis centered on understanding the rationale behind the international expansion of each SE, the scaling strategies deployed, the challenges faced by the parent organization to disseminate socially oriented values and practices across organizational units located overseas, the solutions implemented to manage international expansion challenges, and whether and how these solutions allowed scaling social impact across borders. We only began cross-case analysis once most data had been collected and we had a good understanding of each case in order to preserve the integrity of replication logic across cases [46]. We used visualization tools such as spreadsheet tables, charts, and timelines to look for the emergence of similar themes and patterns across multiple cases [47]. This process of data analysis was not linear, as it involved moving recursively among data, emerging patterns, and existing theory and research [45]. This permitted a synthesis anchored both theoretically in the literature and empirically in our data [38].

\section{Results}

The following subsections report the findings of the research, focusing on the perception of international expansion and rationale behind each scaling strategy, as well as on the challenges and solutions to scale social impact across borders associated with each scaling strategy. The main differences found across the different scaling strategies are summarized in Table 2. 
Table 2. Rationale, strengths, challenges, and solutions associated to each scaling strategy.

\begin{tabular}{|c|c|c|c|c|}
\hline Scaling Strategy & $\begin{array}{l}\text { Rationale behind } \\
\text { International Expansion }\end{array}$ & Main Strengths & Main Challenges & Main Solutions \\
\hline Altruism-based scaling & $\begin{array}{l}\text { Proactive strategy to identify } \\
\text { and exploit social } \\
\text { entrepreneurship opportunities } \\
\text { across borders }\end{array}$ & $\begin{array}{l}\text { Wide and quick dissemination } \\
\text { of the social innovation while } \\
\text { not requiring a high } \\
\text { commitment of financial } \\
\text { resources or increasing } \\
\text { organizational size }\end{array}$ & $\begin{array}{l}\text { - Potential perversion or distortion of the original approach or innovation } \\
\text { when it is replicated by third parties } \\
\text { - Difficulties in replicating the social innovation in regions which are } \\
\text { institutionally and geographically distant from where it originally sourced. }\end{array}$ & $\begin{array}{l}\text { - Hiring the services of local intermediary organizations } \\
\text { specialized in scaling and replicating social ventures } \\
\text { - Support from the source organization in the correct replication of } \\
\text { the social innovation by third parties (e.g., through training } \\
\text { and consultancy) }\end{array}$ \\
\hline Control-based scaling & $\begin{array}{l}\text { Defensive strategy to survive in } \\
\text { highly competitive and } \\
\text { globalized markets }\end{array}$ & $\begin{array}{l}\text { High control over how the } \\
\text { approach or social innovation is } \\
\text { replicated across borders. }\end{array}$ & $\begin{array}{l}\text { - Preserving stakeholder involvement in decision making, social capital, and } \\
\text { local ties as the organization increases in size. } \\
\text { - Replication of the parent organization's characteristic practices and values } \\
\text { in institutionally and geographically distant subsidiaries }\end{array}$ & $\begin{array}{l}\text { - Recovery of discourses emphasizing democracy, social } \\
\text { transformation, and community development } \\
\text { - Reinforcement of social accounting and participatory governance } \\
\text { - Updating and institutionalization of education and training in } \\
\text { mission-driven values }\end{array}$ \\
\hline Hybrid scaling & $\begin{array}{l}\text { Mixed approach that seeks to } \\
\text { scale social innovations quickly } \\
\text { while maintaining some } \\
\text { financial and organizational } \\
\text { control }\end{array}$ & $\begin{array}{l}\text { Potential to generate the widest } \\
\text { variety of social impact } \\
\text { increments }\end{array}$ & $\begin{array}{l}\text { - Alignment of the multiple and often competing goals and logics of the } \\
\text { diverse network partners, especially in the case of cross-sector partnerships } \\
\text { comprising organizations from institutionally and geographically } \\
\text { distant regions } \\
\text { - Potential lack of organizational legitimacy from stakeholders if the social } \\
\text { enterprise partners with mainstream for-profit corporations }\end{array}$ & $\begin{array}{l}\text { - Practices geared at aligning the network's partners around a } \\
\text { shared social mission, identity, and values } \\
\text { - Legitimacy-building activities that clearly make visible an } \\
\text { adequate balance between financial performance and social welfare } \\
\text { outcomes to stakeholders }\end{array}$ \\
\hline
\end{tabular}




\subsection{Perception of International Expansion and Rationale beyond the Process}

Perception of international expansion and rationale beyond pursuing this process differ significantly across the different scaling models.

SEs deploying altruism-based scaling tend to pursue international expansion proactively, as this process is deemed an opportunity to scale their social innovations across borders. Ownership and appropriation of financial value generated by third parties are not relevant for these SEs. As reported by Vickers and Rosen [52], Aravind's Projects Director referred to this idea as follows:

"Achieving scale and improving productivity has enabled us to keep costs down and treat hundreds of thousands of patients each year. It has allowed us to give back to society, to the communities." [52] (p. 27)

These SEs deploy altruism-based scaling strategies because these allow spreading the social innovation or approach more widely and quickly, while not requiring a high commitment of financial resources or increasing their organizational size. A member involved in the replication of Hippocampus Learning Centres (HLC) in Mexico reflected on the dissemination of the approach across the country as follows:

"Something as simple as openly sharing our methods, processes and best practices is helping us to quickly spread our approach across the country (...) This form of expansion allows us to overcome barriers such as seeking funding, recruiting and selecting staff ... that would otherwise require us much more time." [53] (p. 12)

SEs deploying control-based strategies, meanwhile, adopt international expansion as a business strategy to increase the scale of operations, to acquire new capabilities, and to access resources in new geographic markets. Internationalization in these SEs is perceived as a defensive strategy necessary to preserve their competitive position in highly globalized and dynamic markets. In the words of a top manager from a Mondragon industrial cooperative, cited in Bretos and Errasti [54]:

"Many of the Mondragon cooperatives are in highly globalized competitive sectors. At the end of the day, if we want to survive in these sectors ( ... ) we must follow our customers and be present in the main world markets ( ... ). Internationalization has been fundamental for keeping cooperative employment in our plants and, further, we have also created jobs and wealth abroad." [54] (p. 37)

Cross-border scaling up of social impact is understood in these SEs as the reproduction and diffusion of their characteristic cooperative culture, democratic governance practices, social values, and community goals across their multinational network made up by culturally and geographically distant subsidiaries. For instance, this is how Up Group's general manager refers to the commitment of the co-op to the international scaling up of their social impact:

"[The goal is] to spread our cooperative principles, which are well-known in France, to the international scale, because that is where we are now. This involves 17 countries, each with their own different cultures, methods and identities." [55]

SEs adopting hybrid scaling strategies appear to seek to ensure the benefits from both altruismand control-based models. On the one hand, these SEs expand beyond national borders proactively by adopting hybrid strategies (social franchising and strategic alliances), as these allow replicating its model quickly and increasing its impact widely at a limited cost. On the other hand, these SEs seek to exert certain organizational control and to guarantee partial appropriation of the surpluses and value generated. Yet, it is evident that social value scaling is more important relative to financial value capture. Another distinguishing feature of SEs that adopt hybrid scaling strategies is the emphasis on the need to partner with others in order to achieve broad social mission diffusion and scale social impact. This is how one of JUMP's founders expressed this idea: 
"We soon realized that it's impossible to achieve our social goals by working alone (...). To increase social value we must partner not only with other organizations in the Social Economy ecosystem, but also with other actors such as governments, universities, impact investors, donors and corporations." [56] (p. 4)

Whereas differences across the scaling strategies are significant, it is equally evident that these international SEs share some common elements. Two critical aspects are noteworthy. Firstly, all of the case-study SEs perceive their international expansion as a novel process due to the absence of "ready-to-wear" models or templates. For instance, Up Group's general manager referred to the project of extending their cooperative practices and values across their foreign subsidiaries as "a kind of open-air experimentation", stressing that "there is no existing template to work from" [55]. This scarcity of proven templates to scale social impact across borders has led to these SEs innovating in their international expansion strategies. This is how a member of the Impact Hub parent organization cited by Giudici et al. [39] explained the need to introduce innovations in its franchising strategy:

"We constantly had to innovate ... innovation was both a need and an inherent motivation to co-create something together worth doing ( ... ). Unlike the [commercial] franchise approach ... we were driven by purpose and by the ability to respond to societal goals: we had to seek a form to support that." [39] (p. 12)

Secondly, all of the case-study SEs involve a broad range of stakeholders in the decision-making process related to the design and implementation of the international expansion strategy, thus integrating their interests and concerns in the process of scaling social impact. This is how an Up Coop's senior manager emphasized this aspect:

"Entering a new [geographical] market is a long process subject to different, and many times conflicting, perspectives. We hear many voices and consider their input (...). Our employee-members, the management committee, trade unions, the local cooperative movement, local governments... [International expansion] decisions meet very different [stakeholders] interests." [57]

\subsection{Challenges and Innovations to Scale Social Impact across Borders}

International expansion involved important challenges for all the SEs analyzed to maintain a sustainable balance between social welfare and market goals, as highlighted by one of the HLC's founders: "We're trapped between the goal of creating an impact and securing returns at the same time" [58]. Challenges for all of these international SEs involved not only preserving their community embeddedness and socially oriented practices and values, but also extending these across their international networks made up by branches, partners, and/or implementers. These SEs are urged to pursue the societal concerns of a broader range of local communities and the mutual benefits of the diverse stakeholders affected by their activities, which, in many cases, implies the need to implement their social innovations or approaches in culturally and institutionally distant contexts. As reported by Cronin [59], this is how the Director of Programs at HLC expressed the importance of adapting its model to the local context:

"The most important factor is aligning with local norms. India is extremely diverse. There are a million different factors that change in rural areas. If you want to successfully scale across all of them, your curriculum needs to be sensitive enough to emanate from each rural area." [60] (p. 227)

At the same time, these international SEs are pressured to meet increased efficiency and financial performance requirements. In some cases, these requirements are associated with competing with investor-owned multinationals in highly globalized and dynamic markets. In other cases, greater emphasis on financial performance improvement stems from operating in a context of ever-increasing 
stringent requirements to gain funding and pressures for accountability. Regardless of the reasons, international expansion processes in SEs are expected to combine both market and social goals at their very core. The following words by an Up Group's manager reflect this issue:

"Our goal is to maintain our economic strength and succeed in all markets where we are present, but always with the marked social aspect that characterizes our way of managing the group's companies.". [57]

We now turn to discuss some challenges that are more specifically associated with each of the cross-border scaling strategies identified, as well as how the case-study SEs were able to design and implement different solutions and innovations to overcome the challenges encountered and thus scale social impact across borders.

\subsubsection{Control-based International Scaling Strategies}

The three case-study SEs deploying control-based growth strategies experienced significant tensions and challenges to maintain their cooperative practices and social values as they achieved organizational growth in terms of expanding business operations, recruiting new members, and acquiring new clients. Growth has led these SEs to become more bureaucratic and formalized, and to experience a decline in grassroots members' activism and participation in decision making in favor of management control due to the influence of several factors. A key issue is that members find it more difficult to perceive a direct and tangible effect of their involvement in the organization as membership increases in number and heterogeneity, and it also becomes more difficult to establish an efficient flow of information between rank-and-file members and management. This is how a worker-member of a Mondragon industrial cooperative refers to the progressive decline of members' involvement and delegation of decision-making power in management:

"As we have grown in size, ( . . ) the feeling of co-responsibility among the members has progressively diluted ( ... ), and we have lost the ideological sense of the cooperative as a differentiating element from capitalism. The human factor, which is the most important aspect of cooperativism, has been relegated to the background." [60]

Growth has also resulted in the loss of organizational social capital. As these SEs have increased in size, it has become harder to foster trust and personal relationships due to the lesser geographical and social proximity among members. Furthermore, the growing need for managerial expertise in these SEs to thrive in highly competitive and dynamic markets has resulted in the prioritization of a business-like rhetoric that privileges competitiveness, economic efficiency, growth, and customer orientation at the expense of social goals and values such as democracy, equality, mutual help, and solidarity. Overall, this has resulted in weakening of the embeddedness of these SEs in their local communities due to the lessening of communal trust and local ties with community actors.

Furthermore, the case-study SEs have encountered strong internal tensions and external criticism because their international expansion has been based on the setting up of capitalist subsidiaries and for-profit offshoots in which employees are deprived from the same membership rights and benefits compared to those of the member-owners at the parent organization.

However, in the last few years, these SEs have implemented different strategies aimed at refreshing the original aspects of their cooperative model, including social and community transformation, democratic governance, and cooperative training and education. For example, Arla Foods has recently organized different training initiatives for the farmer-owners, focused not only on business issues, but also on the organization's cooperative culture and community orientation [61]. Up Group has reinforced democratic governance through different mechanisms, including the creation of a European Works Council to promote employee voice and social dialogue in the group [62]. Several Mondragon cooperatives have promoted a plethora of community projects aimed at wider societal transformation through different activities such as reinvestment of profits in the community, implementation of 
environmental sustainability goals and circular economy practices, and cooperation with other local organizations that work with people with disabilities and at risk of social exclusion [63]. It is particularly noteworthy that in April 2020, several Mondragon industrial cooperatives temporarily restructured their manufacturing processes to produce and supply face masks and respirators to combat the COVID-19 disease in Spain, in a context of medical equipment shortage and national emergency [64].

These SEs also stand out for having found formulas to implement the cooperative management model and social values in their capitalist subsidiaries. Arla Foods implemented the "Good Growth" strategy in 2015, which aims to combine business growth and expansion with a strong commitment to social responsibility and environmental sustainability. One of the pillars of this strategy is the deployment of cooperative growth, which involves growing through cooperating with different stakeholders for mutual benefit, as well as pursuing the enlargement of the cooperative's membership base and extension of democratic control. In this regard, in recent years, Arla Foods has offered many farmers in its subsidiaries located in culturally and geographically close countries the possibility of becoming owner-members of the cooperative. Today, Arla Foods is owned by 9759 farmers from Sweden, Denmark, Germany, the UK, Netherlands, Belgium, and Luxembourg, thus standing out as one of the few European agrifood cooperatives with a transnational cooperative membership base and governing bodies with representatives from different countries [61].

Meanwhile, several domestic subsidiaries in the Mondragon network and Up Group have been converted to cooperatives. For example, in 2016, three French subsidiaries were integrated as part of the Up Group's parent co-op, with 250 employees becoming shareholder owners. Similar cooperativization processes have been developed in several Mondragon industrial cooperatives in the last decade [65]. The direct transformation of subsidiaries into cooperatives abroad, however, is much more complex due to different barriers. The most relevant include the potential lack of a strongly rooted cooperative culture in many foreign regions in which these SEs have operations, as well as the fact that in the destination country, either no cooperative legislation has been developed, or the legislation in place bears no similarity to that of the parent co-op's country of origin [66].

To overcome these barriers, both Mondragon and Up Group have designed intermediate solutions. These involve replicating the cooperative management model and disseminating the cooperative culture and values in the foreign subsidiaries so that these operate in a similar way to that of the parent co-op, even though they are not formally transformed into a co-op. Several Mondragon co-ops have significantly advanced in the cross-border transfer of various cooperative-like practices, especially in some Latin American and European countries, in which the cultural and institutional distance to the Basque Country is less marked. Meanwhile, Up Group launched, in 2017, the "Roots and Wings" strategy, which comprises a series of cooperative principles and commitments to introduce them across all of the group's subsidiaries (see Table 3).

Table 3. Up's principles and commitments in introducing the co-operative model in foreign subsidiaries. Source: [62] (p. 10).

\begin{tabular}{|c|c|}
\hline Principles & Commitments \\
\hline Driving participatory governance & $\begin{array}{l}\text { - Regularly inform and exchange information with employees on strategies, objectives, } \\
\text { and results for the Group and the subsidiaries. } \\
\text { - Encourage employee representation and engagement within the company to foster } \\
\text { social dialogue. }\end{array}$ \\
\hline Ensuring full social responsibility & $\begin{array}{l}\text { - Take action that benefits the community at large. } \\
\text { - Maintain balanced relations with the stakeholders. }\end{array}$ \\
\hline $\begin{array}{l}\text { Developing a cooperative } \\
\text { management system }\end{array}$ & - Coordinate, mobilize, and unite the collective to empower and involve the employee. \\
\hline $\begin{array}{l}\text { Thinking of the company as a } \\
\text { source of individual development }\end{array}$ & $\begin{array}{l}\text { - Think of work as a factor for personal development. } \\
\text { - Foster equality and diversity and encourage peaceful coexistence. } \\
\text { - Organize financial and social protection of the employees and their families. }\end{array}$ \\
\hline $\begin{array}{l}\text { Creating wealth to foster } \\
\text { development and share it in } \\
\text { compliance with Group values }\end{array}$ & $\begin{array}{l}\text { - Spread the wealth produced collectively in accordance with the values of the Group } \\
\text { (distribute some of the income: incentives, profit sharing, etc.). } \\
- \text { Ensure the sustainability of the company. }\end{array}$ \\
\hline
\end{tabular}




\subsubsection{Altruism-based International Scaling Strategies}

A key challenge faced by SEs deploying altruism-based scaling processes is the lack of control mechanisms regarding who replicates the approach or social innovation, for which purpose it is implemented, and whether its quality and essence are preserved. This can result in a distortion of the approach and consequent damage to the brand image of the source organization, if the approach/innovation is not adequately applied; that is, if the social mission or innovation is perverted by pursuing purely economic goals or other personal concerns that go against the general interest or the interest of the target audience.

HLC experienced some problems related to the distortion of its original approach during its initial expansion in India, because some educational programs were not being replicated with the expected quality and some centers were not financially sustainable on their own. Similar problems were evident in Aravind. This is how a senior member cited by Lehman [67] referred to some of the problems Aravind encountered in replicating its model in other hospitals in its early days:

“... in consulting, we act as a catalyst, we cannot directly say 'it is because of me'. Because, once we act as catalyst and they [implementers] receive the ideas, they'll start doing it. ( ... ) [T] here are hospitals [that] are not done well because of lack of or frequent change of leadership or lack of availability of doctors or they're not following the processes they should." [67] (p. 77)

In the case of Freecycle, the parent organization repeatedly reported that some local groups outside of the United States had adopted the brand Freecycle but did not represent the original approach, since members did not vote on a democratic basis and in accordance with communal rules. It was even claimed that some local group leaders used the Freecycle brand to increase membership, and then took the members for their own personal gain.

However, the responses to this challenge-namely, the lack of control over how the implementer adopted the original innovation or approach—varied significantly across the case-study SEs. The Freecycle US parent has been found to gradually move toward more autocratic monitoring models that stifle the adaptation of the approach to the local context in which it is being replicated, thereby seriously damaging the ties between Freecycle groups and local communities. This has resulted in hundreds of local branches across different countries abandoning The Freecycle Network to establish independent free reuse groups or to develop parallel networks. The case of the UK is probably the most significant one, especially taking into account that this country hosted $10 \%$ of all The Freecycle Network branches and handled $27 \%$ of all activities [68]. In 2009, most UK local groups broke away to set up the alternative network Freegle under accusations of increasing tight control from the US Freecycle parent and little room of maneuver for local adaptation, as well as growing concerns over the gradual erosion of Freecycle's grassroots ethos [69]. As noted by the former director of UK Freecycle in an interview for The Guardian:

"[The network's US management] had a very set way of doing things, and we could not adapt that to what works best here ( . . . ). I think there was a very real wish to keep very tight control over the organization, rather than let it flourish by the efforts of the volunteers." [68]

The cases of Aravind and HLC, meanwhile, illustrate how SEs can deploy altruism-based strategies to scale social impact across borders in an efficient way that prevents the distortion of the original approach by the implementer and, at the same time, avoids the exertion of excessive centralized control that might hinder the replication and local adaptation of the approach beyond national borders.

HLC solved problems related to the lack of quality in education programs and poor financial performance in some centers that had opened in India by investing in the recruiting and training of local rural teachers to run each center. When HLC embarked on the process of disseminating its model to Mexico in 2016, however, it hired the services of Connovo, a local social business specializing in the replication of social ventures to scale impact. The replication venture-builder, Connovo, was also 
crucial in acquiring the knowhow to adapt the HLC model to the Mexican local context. For example, the financing model in Mexico is very different from that in India, as the Mexican learning centers are funded by large local companies. This is how a member of HLC's management team explained this experience:

"When the opportunity arose to replicate our model in Mexico, we considered various options, but from our previous experience in India we quickly realized that we would need an intermediary, not only to ensure that our model is correctly replicated by maintaining the quality of our educational programs and our original essence, but also to achieve the necessary adaptation to the Mexican context and to be able to generate a network of trust and closeness with different local actors." [53] (p. 7)

Aravind's solution to the lack of control over the replication of its original approach was the creation of the Lions Aravind Institute of Community Ophthalmology (LAICO) in 1992. LAICO is the training and consulting arm of Aravind Eye Care System and was established with the mandate to support eye care programs globally through consultancy and capacity building, management training, and research. In particular, its services range from passive services that only allow for systematic visits and workshops for client staff at LAICO, to more active accompaniment and support for replication of the model through a two-year consultancy process that includes assessment, capacity-building and strategic planning, on-site implementation guidance and training, and off-site monitoring and advice [36].

As noted by Sezgi and Mair [34], LAICO has been crucial in disseminating Aravind's model, a process that is based on four mechanisms: (1) Training of organizational members to teach them skills and to instill values; (2) rotating organizational members to spread values in newly established hospitals; (3) ensuring communication between hospitals, both to monitor performance and to reinforce the maintenance and spread of values; and (4) providing updated templates containing their best practices to be shared with third-party hospitals. In particular, LAICO has trained 2660 professionals from 81 countries and has worked with over 300 hospitals in India and another 30 countries across South-East Asia, Africa, and Latin America. Furthermore, some of the hospitals trained by Aravind are, in turn, disseminators of the model in their own regions. For example, the Visualiza hospital in Guatemala is disseminating the approach across Haiti and Peru.

\subsubsection{Hybrid International Scaling Strategies}

A critical challenge for SEs deploying hybrid strategies to scale social impact lies in the potential problems in aligning interests with the partner organizations, and thus in achieving the appropriate balance between financial and social goals across the network.

In the case of social franchising, this tension takes the form of the potential lack of goal alignment between the franchisor and the franchisee, since one party might prioritize social mission while the other party might overemphasize financial concerns.

Impact Hub illustrates the emergence of these problems in social franchise systems, as well as how SEs can resolve goal incongruence tensions and scale social impact. After the vertiginous growth experienced by Impact Hub in its first five years, the need to define a governance structure was resolved with the creation of Hub World, a limited company with Jonathan Robinson-co-founder and informal leader of Impact Hub - as the sole shareholder. The decision was influenced by investors' pressures, as well as by the desire of the central organization to have greater control to prevent the adhesion of individuals and organizations that might not share Impact Hub's social mission. This new structure, however, immediately led to a conflictual period, as many local Hubs perceived this change as a departure from the organization's social principles, and some of them stopped paying their franchise fees. As reported by Bachmann [70], this was recognized by Robinson in the following terms:

"There was tension in the network over whether we should pursue nonprofit or for-profit.

There were big questions around how much to invest in the core, on what terms, and for 
what services. And ( ... there was growing tension around ownership. The fact that one person owned the brand was not aligned with what we had collectively created." [70] (p. 22)

After a year of turmoil, a new leading team took control and restructured Impact Hub to reconcile its social and commercial goals and to successfully scale social value. This basically involved the promotion of decentralized decision making and the alignment of franchisor-franchisee relationships around a shared social mission, identity, and values [38]. A new central organization, Hub Association, was created in the form of a non-profit association co-owned by all local Hubs as equal shareholders, and whose operation is based on the rule of "one Hub, one vote" [70]. As a member from Impact Hub headquarters explained, "What we have done is to elevate shared purposes, shared principles, and shared values ... with the intent to hold each other to account" [38] (p. 14). The alignment of franchisees around Impact Hub's social mission has been promoted not only through shared ownership and governance, but also through the introduction of different practices aimed at creating a sense of community within the network, which include the organization of events and training workshops for members from different local Hubs.

In cross-sector partnerships, meanwhile, a key source of tension is the existence of multiple and potentially contradictory goals, beliefs, and governance structures. A major challenge for SEs engaging in partnerships with for-profit corporations lies in the adoption of business-like practices at the expense of social mission, due to the latter's influence, especially in power-unbalanced partnerships. Ultimately, this can jeopardize organizational legitimacy from stakeholders, who might perceive partnering with for-profit corporations as a "pact with the devil" [71].

The case of Ben \& Jerry's illustrates these challenges. In 2000, it was acquired by Unilever. While this operation was actually a takeover, it was described by some as a "partnership agreement," because Ben \& Jerry's retained total autonomy to make decisions and to pursue its own agenda within Unilever [72]. Despite this special status, the acquisition resulted in significant criticism from employees, customers, suppliers, donors, and social activists, who perceived that Ben \& Jerry's had drifted away from its social and ecological roots. For example, Ben \& Jerry's employees had to stop using their brand in political campaigns, such as anti-war demonstrations, because Unilever's ethical code required the company to remain apolitical. Four years after the acquisition, only $30 \%$ of the employees believed that Ben \& Jerry's had remained true to its social agenda [73].

In 2009, however, changes in the board of directors led to a period of reinvigorating mission-drive practices and values, with Ben \& Jerry's even influencing Unilever to become a more socially responsible multinational [72]. Since then, a wide range of initiatives have been implemented, including the commitment to purchasing 100\% fair trade ingredients where possible, the agreement with an SE that employs homeless people to produce the Ben \& Jerry's brownies, the development of environmentally friendly innovations (e.g., carbon-neutral freezers), and the support for several political campaigns and philanthropic activities. Interestingly, in 2010, $83 \%$ of the employees reported being proud to work for Ben \& Jerry's [73]. Ben \& Jerry's has also changed its communication strategy to more clearly emphasize its social and environmental outcomes. Indeed, in 2012, Ben \& Jerry's applied for and achieved B Corp certification, thus sending a clear message to its stakeholders, as the Board Chair suggested:

"Becoming a Certified B Corp is an important step, not only because it re-affirms our deep commitment to values-led business practices, but also because it affirms how Ben \& Jerry's and Unilever work together to advance our Social Mission." [74]

The case of Join Us to Maximize our Potential (JUMP) equally reveals how SEs can benefit from partnering with mainstream corporations to scale social impact while maintaining organizational legitimacy from stakeholders. In 2013, JUMP formed a partnership with Hyundai Motor Company (HMC) to implement the program "H-Jump School." This program basically consists of underprivileged adolescents getting tutoring and mentoring by volunteer university student tutors for one year, while these university students get career consultation from professors, company executives, and social 
entrepreneurs [75]. As explained by a member of JUMP's board, this operation prompted wide criticism from stakeholders, both within and outside the company:

"Some internal tensions arose because many did not understand that we were partnering with a multinational company like Hyundai to address the problem of unequal educational opportunities (...). Other partnerships we had in the Social Economy sector came under threat because some social enterprises were not comfortable with this situation." [56] (p. 11)

To solve these tensions, JUMP organized meetings with different stakeholders to explain the benefits of the Hyundai partnership to scale social impact. Among other issues, JUMP emphasized HMC's brand power to obtain the credentials needed to recruit the best university student teachers for the fulfillment of its social mission, as well as the access to HMC's managerial knowhow and resources that would otherwise be unavailable [76]. In fact, between 2013 and 2017, 500 university students offered tutoring and mentoring for 2000 underprivileged adolescents. In addition, the success of the H-Jump School program has led HMC to establish other partnerships with SEs. A prominent example is "On-Dream," a program to support young social entrepreneurs. In the words of HMC's corporate social responsibility (CSR) director:

“HMC ... expanded our CSR activities to create a platform to nurture other young and potential social entrepreneurs. So, we launched a new program called 'On-Dream'. This expansion in the CSR activities happened because we achieved great results from the partnerships with JUMP." [76] (p. 13)

\section{Discussion}

It is increasingly recognized that processes of expansion and scaling social innovations beyond local contexts embody a critical mechanism for SEs to generate sustainability transitions and welfare-enhancing systemic change [16-18,22,23]. While prior research has significantly advanced the knowledge of the diverse typologies of scaling strategies deployed by SEs [14], we poorly understand how processes of scaling social impact take place on an international scale. In this paper, we conceptualized the international expansion of SEs as a catalyst for scaling up social impact across borders. Accordingly, we portrayed international SEs as key "institutional entrepreneurs" [77], with the potential to contribute to addressing growing large-scale environmental and social issues that are global in nature, such as poverty, worsening of health and living conditions, impoverished labor conditions, social exclusion, biodiversity depletion, and climate change [24]. We specifically contributed to the literature in three ways.

Firstly, our research shed light on the role played by a variety of initial conditions and factors in shaping the subsequent process and pathways of scaling social impact in SEs, as recently requested by some authors $[23,28,29,78]$. The main factors identified in our research include the SE's perception of growth and scaling social impact, the rationale and motivation behind the decision to expand across borders, the desired degree of organizational control, the capacity of resource commitment, and the desired speed of escalation. These factors significantly vary across the three main cross-border scaling strategies that we discerned: Control-based, altruism-based, and hybrid.

As seen, SEs operating in highly globalized and competitive markets tend to internationalize as a defensive, survival strategy and, therefore, adopt control-based strategies, as these allow exerting centralized control and partially capturing the financial value generated by their foreign offshoots. This strategy appears to be based on a "mutual interest" orientation, as described by Bauwens et al. [27], as international expansion is ultimately pursued as a way to protect the SE's owner-members' benefits. Consequently, scaling social impact is understood in these SEs as the process of transferring their hallmark cooperative practices and values to their foreign offshoots. Altruism-based strategies, in contrast, are prone to be used by SEs that proactively pursue international expansion in order to identify and exploit "social entrepreneurship opportunities" [10] in a context in which global economic, social, and environmental problems are not being effectively addressed by the public 
and for-profit sectors [9]. Accordingly, these SEs deploy mechanisms that allow the quick and wide replication of their innovation or approach, rather than those granting financial and organizational control. Altruism-based scaling seems to be more closely linked to a "general interest" orientation, which goes beyond members' interests by targeting broader social groups or the society as a whole [27]. Hybrid scaling strategies are more likely to be used by SEs seeking trade-off solutions that allow extending their social mission beyond national borders relatively quickly and at a limited cost, while ensuring mechanisms to control how their approach or innovation is being disseminated. By partnering with other organizations, these SEs appear to be able to generate the widest variety of social impact increments. These include reaching a larger number of beneficiaries, widening the diversity of services offered to the same target population, and inducing their for-profit partners to behave more socially and/or environmentally responsible.

Secondly, we contributed to an emerging strand of research interested in elucidating the tensions and ethical challenges faced by SEs when they engage in the process of scaling up their ventures $[4,15]$. While a number of studies have uncovered some social-business tensions associated with the growth and scaling up of SEs operating on a local scale (see Zhao and Han [4] for a review), our study examined such tensions within international SEs, a field of research that has been largely ignored in the previous literature on social-business tensions in SEs [79]. Our research revealed how tensions to balance financial performance goals and social and/or environmental concerns, which are inherent to SEs as "hybrid organizations" [66], are exacerbated when these organizations engage in cross-border scaling processes. In this regard, international SEs have to pursue the societal concerns of a broader range of local communities and the mutual benefits of the diverse stakeholders affected by their activities, which, in many cases, are located in culturally and institutionally distant contexts. At the same time, these SEs are pressured to meet increased efficiency and financial performance requirements, either because they are competing against for-profit multinational corporations in highly globalized and dynamic markets, or as a response to ever-increasing stringent requirements to gain funding and growing pressures for accountability.

In addition, our research illustrated how each scaling strategy is associated with a set of distinctive tensions and challenges, thus enriching ongoing debates about the relationship between scaling and mission drift pressures in SEs [7,13]. For example, control-based scaling strategies are likely to threaten the fulfillment of the social mission and jeopardize democratic governance practices, because stakeholder involvement in decision making, social capital, and local ties becomes harder to promote as the SE increases in size. SEs deploying control-based strategies also face important barriers of an institutional and cultural nature to disseminate their characteristic cooperative practices and social values across their foreign subsidiaries. In the case of SEs adopting altruism-based scaling strategies, the main challenge is the potential perversion or distortion of the original approach or innovation when it is replicated by third parties. In SEs adopting hybrid scaling strategies, meanwhile, a major challenge lies in the alignment of the multiple and often competing goals and logics of the diverse network partners. This is especially critical when partnering with for-profit corporations, which might lead the $\mathrm{SE}$ to prioritize market concerns at the expense of its original mission-driven goals, thus compromising organizational legitimacy from stakeholders.

Thirdly, we addressed recent calls in the scholarly literature to explore the approaches that SEs can adopt to manage the challenges associated with international expansion and, thus, scale social impact across borders [2,9]. Overall, the evidence gathered from all of the case studies clearly supports the paramount importance of adapting the approach or innovation to the local context, so that it is aligned with local resources, concerns, and challenges. More specifically, our research uncovered how international SEs can mobilize resources and activate processes of organizational change not only to prevent mission drift, but also to counterbalance degenerative processes and thus to recover the expected equilibrium between social welfare and financial logics.

In SEs deploying control-based scaling strategies, the key approaches to prevent and countervail mission drift include the recovery of discourses emphasizing democracy, social transformation, and 
community development; the reinforcement of social accounting and participatory governance; and the updating and institutionalization of education and training in mission-driven values. In SEs scaling through altruism-based strategies, solutions include hiring the services of local intermediary organizations specialized in scaling and replicating social ventures, and the support from the source organization in the correct replication of the solution or innovation by third parties, for example, by providing them with training and consultation. In SEs using hybrid strategies, it seems essential to introduce practices geared at aligning the network's partners around a shared social mission, identity, and values, as well as to carry out legitimacy-building activities that clearly make visible an adequate balance between financial performance and social welfare outcomes to stakeholders.

\section{Conclusions}

In conclusion, this article showed how SEs of different sizes can successfully operate on an international scale, deploying a wide variety of expansion strategies that respond to different rationales and that result in diverse typologies of scaled social impact. Our research revealed that international SEs can simultaneously generate financial, social, and environmental outcomes, thus preserving the distinctive values, practices, and orientations that make them genuine alternatives to corporate managerialism in the international business arena. These findings challenge received wisdom and mainstream theory portraying SEs as small-sized organizations that exclusively operate on a local scale due to different limitations and inefficiencies to grow, as well as deterministic predictions suggesting that international expansion unavoidably leads the SE to experience mission drift (see Bretos et al. [8] for a detailed critique).

The study has practical implications for social entrepreneurs and professionals in social economy organizations interested in replicating or disseminating their approach or social innovation across borders. In this regard, the article shows a variety of strategies available for SEs to scale up their venture and social impact, potential challenges they might encounter along the way, and possible solutions to preserve the sustainability of the social venture and maximize social impact. A crucial practical lesson drawn from our findings is that enforcing a model into recipient communities according to the standards of the region of origin simply does not work. Accordingly, practitioners should consider adapting their approach or social innovation to the conditions and characteristics of the local context in order to ensure the success of the replication or dissemination process and effectively scale social impact. In addition, our research findings can be also of practical relevance for international entrepreneurs and managers of multinational companies looking to implement more sustainable patterns of international expansion and engage in more responsible behaviors in social and environmental terms. This seems to be particularly pressing in a context in which multinational companies are in the spotlight due to recurrent ethical dilemmas and are expected to seriously address sustainable development targets $[9,24]$.

This research was exploratory in nature, representing a first step in understanding the challenges faced by SEs when they engage in international expansion, as well as their strategic responses to manage such challenges and scale social impact across borders. An important limitation is that the study does not examine the concurrent deployment of multiple cross-border scaling strategies by SEs and its impact on the nature, scope, and depth of social impact. Future research could henceforth explore the synergies of simultaneously combining different international scaling strategies. Another promising avenue for future research lies in examining how institutional ecosystems in the home and recipient regions shape SE cross-border scaling decisions, processes, and outcomes. Regions in which both formal and informal institutions are highly supportive of social economy practices, such as the Basque Country in Spain and Emilia-Romagna in Italy [80], might form a prolific field to start studying these issues. Lastly, bearing in mind the plurality of the drivers and motivations behind SE expansion [78], as well as the organizational diversity within the social enterprise sector [40], future research might also investigate other pathways of cross-border scaling and examine the patterns in the management of the resulting challenges to increase social impact within international SEs operating in different industries and national settings. 
Author Contributions: Conceptualization, I.B.; M.D.-F., and C.M.; methodology, I.B.; software, I.B.; validation, I.B., M.D.-F., and C.M.; formal analysis, I.B.; data curation, I.B., M.D.-F., and C.M.; writing-original draft preparation, I.B.; writing-review and editing, I.B., M.D.-F., and C.M.; funding acquisition, M.D.-F., and C.M. All authors have read and agree to the published version of the manuscript.

Funding: This research was funded by the Regional Government of Aragon and the European Regional Development Fund [Construyendo Europa desde Aragón], grant number "GESES S28_17R".

Acknowledgments: The first author acknowledges the invaluable support of Patricia Ares Bel and Carmen Fernández Ortiz del Rio.

Conflicts of Interest: The authors declare no conflict of interest.

\section{References}

1. Bloom, P.N.; Skloot, E. Scaling Social Impact: New Thinking; Palgrave Macmillan: New York, NY, USA, 2010.

2. Seelos, C.; Mair, J. Innovation and Scaling for Impact; Stanford University Press: Stanford, CA, USA, 2017.

3. Desa, G.; Koch, J.L. Scaling Social Impact: Building Sustainable Social Ventures at the Base-of-the-Pyramid. J. Soc. Entrep. 2014, 5, 146-174. [CrossRef]

4. Zhao, M.; Han, J. Tensions and Risks of Social Enterprises' Scaling Strategies: The Case of Microfinance Institutions in China. J. Soc. Entrep. 2019, 1-21. Available online: https://doi.org/10.1080/19420676.2019. 1604404 (accessed on 16 April 2020).

5. Yang, Y.-K.; Wu, S.-L. An Exploratory Study to Understand the Internationalization Strategies of Social Enterprises. J. Soc. Entrep. 2014, 6, 31-41. [CrossRef]

6. Errasti, A.; Nunez, A.; Bretos, I. The Viability of Cooperatives: The Fall of the Mondragon Cooperative Fagor. Rev. Radic. Political Econ. 2017, 49, 181-197. [CrossRef]

7. Bretos, I.; Errasti, A.; Marcuello, C. Ownership, governance, and the diffusion of HRM practices in multinational worker cooperatives: Case-study evidence from the Mondragon group. Hum. Resour. Manag. J. 2017, 28, 76-91. [CrossRef]

8. Bretos, I.; Foncea, M.D.; Marcuello, C. Cooperativas e internacionalización: Un análisis de las 300 mayores cooperativas del mundo. CIRIEC-España Rev. Econ. Publica Soc. Coop. 2018, 92, 5-37. [CrossRef]

9. Bretos, I.; Marcuello, C. Revisiting Globalization Challenges and Opportunities in the Development of Cooperatives. Ann. Public Cooperative Econ. 2016, 88, 47-73. [CrossRef]

10. Zahra, S.A.; Rawhouser, H.N.; Bhawe, N.; Neubaum, D.O.; Hayton, J.C. Globalization of social entrepreneurship opportunities. Strat. Entrep. J. 2008, 2, 117-131. [CrossRef]

11. Mozas-Moral, A.; Moral-Pajares, E.; Medina-Viruel, M.J.; Bernal-Jurado, E. Manager's educational background and ICT use as antecedents of export decisions: A crisp set QCA analysis. J. Bus. Res. 2016, 69, 1333-1335. [CrossRef]

12. Moreno, A.S.; Sempere, S.P. Análisis de las plataformas de crowdfunding social en el estado español: Un estudio de casos. REVESCO Rev. Estud. Coop. 2019, 130, 149-175. [CrossRef]

13. Datar, S.M.; Epstein, M.J.; Yuthas, K. Enamored with Scale: Scaling with Limited Impact in the Microfinance Industry. In Scaling Social Impact; Bloom, P.N., Skloot, E., Eds.; Palgrave Macmillan: New York, NY, USA, 2010.

14. Han, J.; Shah, S. The Ecosystem of Scaling Social Impact: A New Theoretical Framework and Two Case Studies. J. Soc. Entrep. 2019, 1-25. Available online: https://doi.org/10.1080/19420676.2019.1624273 (accessed on 16 April 2020).

15. André, K.; Pache, A.-C. From Caring Entrepreneur to Caring Enterprise: Addressing the Ethical Challenges of Scaling up Social Enterprises. J. Bus. Eth. 2014, 133, 659-675. [CrossRef]

16. Hudon, M.; Huybrechts, B. From Distant Neighbours to Bedmates: Exploring the Synergies between the Social Economy and Sustainable Development. Ann. Public Cooperative Econ. 2017, 88, 141-154. [CrossRef]

17. Tortia, E.C.; Degavre, F.; Poledrini, S. Why are Social Enterprises Good Candidates for Social Innovation? Looking for Personal and Institutional Drivers of Innovation. 2020, pp. 1-19. Available online: https: //doi.org/10.1111/apce.12265 (accessed on 16 April 2020).

18. Salustri, A. The UN 2030 Agenda and Social and Solidarity Economy: Toward a structural change? Rev. Appl. Soc.-Econ. Res. 2019, 18, 104-117. 
19. Le Blanc, D. Towards Integration at Last? The Sustainable Development Goals as a Network of Targets. Sustain. Dev. 2015, 23, 176-187. [CrossRef]

20. Galli, A.; Djurovic, G.; Hanscom, L.; Knezevic, J. Think globally, act locally: Implementing the sustainable development goals in Montenegro. Environ. Sci. Policy 2018, 84, 159-169. [CrossRef]

21. Salva, A.L.; Filho, W.L.; Brandli, L.; Griebeler, J.S. Assessing research trends related to Sustainable Development Goals: Local and global issues. J. Clean. Prod. 2019, 208, 841-849. [CrossRef]

22. Lubberink, R. Social Entrepreneurship and Sustainable Development. In Decent Work and Economic Growth; Leal Filho, W., Azul, A., Brandli, L., Özuyar, P., Wall, T., Eds.; Springer: Berlin/Heidelberg, Germany, 2019.

23. Westley, F.; Antadze, N.; Riddell, D.J.; Robinson, K.; Geobey, S. Five Configurations for Scaling Up Social Innovation. J. Appl. Behav. Sci. 2014, 50, 234-260. [CrossRef]

24. Doh, J.P.; Tashman, P.; Benischke, M.H. Adapting to Grand Environmental Challenges Through Collective Entrepreneurship. Acad. Manag. Perspect. 2019, 33, 450-468. [CrossRef]

25. Defourny, J.; Nyssens, M. Fundamentals for an International Typology of Social Enterprise Models. Volunt. Int. J. Volunt. Nonprofit Organ. 2017, 28, 2469-2497. [CrossRef]

26. Chaves, R.; Monzón, J.L. La economía social ante los paradigmas económicos emergentes: Innovación social, economía colaborativa, economía circular, responsabilidad social empresarial, economía del bien común, empresa social y economía solidaria. CIRIEC-España Rev. Econ. Publica Soc. Coop. 2018, 93, 5-50. [CrossRef]

27. Bauwens, T.; Huybrechts, B.; Dufays, F. Understanding the Diverse Scaling Strategies of Social Enterprises as Hybrid Organizations: The Case of Renewable Energy Cooperatives. 2019. Available online: https: //journals.sagepub.com/doi/full/10.1177/1086026619837126 (accessed on 16 April 2020).

28. Blundel, R.; Lyon, F. Towards a Long View: Historical Perspectives on the Scaling and Replication of Social Ventures. J. Soc. Entrep. 2014, 6, 80-102. [CrossRef]

29. Cannatelli, B.L. Exploring the Contingencies of Scaling Social Impact: A Replication and Extension of the SCALERS Model. Volunt. Int. J. Volunt. Nonprofit Organ. 2016, 28, 2707-2733. [CrossRef]

30. Dees, J.G.; Anderson, B.B.; Wei-Skillern, J. Scaling social impact. Stanf. Soc. Innov. Rev. 2004, 1, $24-32$.

31. Heinecke, A.; Mayer, J. Strategies for Scaling in Social Entrepreneurship. In Social Entrepreneurship and Social Business; Volkmann, C., Tokarski, K., Ernst, K., Eds.; Gabler Verlag: Wiesbaden, Germany, 2012; pp. 191-209.

32. Lyon, F.; Fernandez, H. Strategies for scaling up social enterprise: Lessons from early years providers. Soc. Enterp. J. 2012, 8, 63-77. [CrossRef]

33. Nazarkina, L. How sustainable are the growth strategies of sustainability entrepreneurs? In Balanced Growth; Mennillo, G., Ed.; Springer: Berlin/Heidelberg, Germany, 2012.

34. Sezgi, F.; Mair, J. To Control or Not Control: A Coordination Perspective to Scaling. In Scaling Social Impact: New Thinking; Bloom, P., Skloot, E., Eds.; Palgrave Macmillan: New York, NY, USA, 2010; pp. $29-44$.

35. Vickers, I.; Lyon, F. Beyond green niches? Growth strategies of environmentally-motivated social enterprises. Int. Small Bus. J. Res. Entrep. 2012, 32, 449-470. [CrossRef]

36. Berelowitz, D.; Chopra, P.; Coussa, G.; Paren, M.; Towner, M.; Wetherill, H.; Huggett, J. Social Replication Toolkit; Spring Impact: London, UK, 2015.

37. Aschari-Lincoln, J.; Jacobs, C. Enabling Effective Social Impact: Towards a Model for Impact Scaling Agreements. Sustainability 2018, 10, 4669. [CrossRef]

38. Tracey, P.; Jarvis, O. Toward a Theory of Social Venture Franchising. Entrep. Theory Pract. 2007, 31, 667-685. [CrossRef]

39. Giudici, A.; Combs, J.G.; Cannatelli, B.L.; Smith, B.R. Successful Scaling in Social Franchising: The Case of Impact Hub. Entrep. Theory Pract. 2018, 44, 288-314. [CrossRef]

40. Thompson, J. The diverse world of social enterprise. Int. J. Soc. Econ. 2006, 33, 361-375. [CrossRef]

41. Horan, D. A New Approach to Partnerships for SDG Transformations. Sustainability 2019, 11, 4947. [CrossRef]

42. Selsky, J.W.; Parker, B. Cross-Sector Partnerships to Address Social Issues: Challenges to Theory and Practice. J. Manag. 2005, 31, 849-873. [CrossRef]

43. Islam, S.M. Unintended consequences of scaling social impact through ecosystem growth strategy in social enterprise and social entrepreneurship. J. Bus. Ventur. Insights 2020, in press. [CrossRef]

44. Davies, I.; Haugh, H.; Chambers, L. Barriers to Social Enterprise Growth. J. Small Bus. Manag. 2018, 57, 1616-1636. [CrossRef]

45. Eisenhardt, K.M. Building theories from case study research. Acad. Manag. Rev. 1989, 14, 532-550. [CrossRef]

46. Yin, R.K. Case Study Research, 5th ed.; Sage: London, UK, 2013. 
47. Eisenhardt, K.M.; Graebner, M.E. Theory Building from Cases: Opportunities and Challenges. Acad. Manag. J. 2007, 50, 25-32. [CrossRef]

48. Beck, C.T. Secondary Qualitative Data Analysis in the Health and Social Sciences; Routledge: London, UK, 2019.

49. Paranque, B.; Willmott, H. Cooperatives-Saviours or gravediggers of capitalism? Critical performativity and the John Lewis Partnership. Organization 2014, 21, 604-625. [CrossRef]

50. Long-Sutehall, T.; Sque, M.; Addington-Hall, J. Secondary analysis of qualitative data: A valuable method for exploring sensitive issues with an elusive population? J. Res. Nurs. 2010, 16, 335-344. [CrossRef]

51. Errasti, A.; Bretos, I.; Etxezarreta, E. What do mondragon coopitalist multinationals look like? The rise and fall of fagor Electrodomésticos S. coop. and its European subsidiaries. Ann. Public Coop. Econ. 2016, 87, 433-456. [CrossRef]

52. Vickers, T.; Rosen, E. Driving down the cost of high-quality care: Lessons from the Aravind Eye Care System. Health Int. 2011, 11, 18-27.

53. HLC. Hipocampus Centros de Aprendizaje; Hippocampus: Ciudad de México, Mexico, 2018.

54. Bretos, I.; Errasti, A. The challenges of managing across borders in worker cooperatives: Insights from the Mondragon cooperative group. J. Coop. Organ. Manag. 2018, 6, 34-42. [CrossRef]

55. Up, Shared Democratic Cooperative Principles. Available online: https:www.youtube.com/watch?v=m HymlSL_fg (accessed on 4 February 2019).

56. JUMP. JUMP's Glocalization Model; JUMP: Seoul, Korea, 2018.

57. Nuestros Productos Crean Vínculos Entre el Trabajador y su Empresa. Available online: https: www.equiposytalento.com/elsector/director-general/up-spain/olivier-bernon/2016-04-03/ (accessed on 12 May 2019).

58. How Hippocampus is Transforming Education in Rural India. Available online: https://smartceo.co/howhippocampus-is-transforming-education-in-rural-india (accessed on 25 May 2019).

59. Cronin, M.J. Impact investing at the base of the pyramid: Unitus seed fund. In Managing for Social Impact; Cronin, M.J., Dearing, T.C., Eds.; Springer: New York, NY, USA, 2017; pp. 217-235.

60. Cuanto Más Grandes Nos Hemos Hecho, Hemos Perdido el Ideario Cooperativista. Available online: https:www.naiz.eus/eu/actualidad/noticia/20131103/cuanto-mas-grandes-nos-hemos-hecho-hemosperdido-el-ideario-cooperativista (accessed on 19 January 2019).

61. Arla Foods Consolidated Annual Report; Arla Foods Amba: Viby, Denmark, 2019.

62. Up Coop. 2017 Extra-Financial Report; Up Coop: Gennevilliers, France, 2018.

63. Bretos, I.; Errasti, A.; Marcuello, C. Is There Life after Degeneration? The Organizational Life Cycle of Cooperatives under a Grow-or-Die Dchotomy. 2019, pp. 1-26. Available online: https://onlinelibrary.wiley. com/doi/abs/10.1111/apce.12258 (accessed on 16 April 2020).

64. La Industria Vasca Contra la Pandemia. Available online: https:www.elcorreo.com/economia/industriavasca-pandemia-20200329030811-nt.html (accessed on 12 April 2019).

65. Bretos, I.; Errasti, A. Challenges and Opportunities for the Regeneration of Multinational Worker Cooperatives: Lessons from the Mondragon Corporation-A Case Study of the Fagor Ederlan Group. Organization 2017, 24, 154-173. [CrossRef]

66. Bretos, I.; Errasti, A.; Marcuello, C. Multinational Expansion of Worker Cooperatives and Their Employment Practices: Markets, Institutions, and Politics in Mondragon. ILR Rev. 2018, 72, 580-605. [CrossRef]

67. Lehman, T. Scaling Social Impact: The Case of Aravind Eye Hospitals. Master's Thesis, Witten/Herdecke University, Witten, Germany, 2009.

68. Accusations of very Tight Control Split UK Recycling Network from US Parent. Available online: https: www.theguardian.com/environment/2009/oct/12/freecycle-freegle-recycling-networks-groups (accessed on 3 June 2019).

69. Martin, C.; Upham, P.; Budd, L. Commercial orientation in grassroots social innovation: Insights from the sharing economy. Ecol. Econ. 2015, 118, 240-251. [CrossRef]

70. Bachmann, M. How the Hub found its center. Stanf. Soc. Innov. Rev. 2014, 12, $22-27$.

71. Huybrechts, B.; Nicholls, A.; Edinger, K. Sacred alliance or pact with the devil? How and why social enterprises collaborate with mainstream businesses in the fair trade sector. Entrep. Reg. Dev. 2017, 29, 586-608. [CrossRef]

72. Edmondson, B. Ice Cream Social: The Struggle for the Soul of Ben E Jerry's; Berret-Koehler Publishers, Inc.: San Francisco, CA, USA, 2014. 
73. Haski-Leventhal, D.; Roza, L.; Meijs, L. Congruence in corporate social responsibility: Connecting the identity and behaviour of employers and employees. J. Bus. Eth. 2017, 143, 35-51. [CrossRef]

74. Ben \& Jerry's Joins the Growing B Corporation Movement. Available online: https:www.businesswire. com/news/home/20121022005170/en/Ben-Jerrys-Joins-Growing-Corporation-Movement (accessed on 13 September 2019).

75. Rhee, J.H.; Bohnsack, R.; Lee, S. Hyundai Motor Company Case-Fostering Social Enterprises. In The Role of Corporate Sustainability in Asian Development; Lenssen, G., Rhee, J.H., Martinez, F., Eds.; Springer: Berlin/Heidelberg, Germany, 2017; pp. 119-143.

76. Park, J.; Hwang, K.; Kim, S.-J. Forming a Social Partnership between a Small Social Enterprise and a Large Corporation: A Case of the Joint Platform, H-JUMP. Sustainability 2018, 10, 3612. [CrossRef]

77. Battilana, J.; Leca, B.; Boxenbaum, E. How actors change institutions: Towards a theory of institutional entrepreneurship. Acad. Manag. Ann. 2009, 3, 65-107. [CrossRef]

78. Tykkyläinen, S. Why social enterprises pursue growth? Analysis of threats and opportunities. Soc. Enterp. J. 2019, 15, 376-396. [CrossRef]

79. Bretos, I.; Errasti, A. La transmisión de los valores y prácticas organizacionales cooperativas en las filiales extranjeras: El caso de la cooperativa multinacional Fagor Ederlan. REVESCO Rev. Estud. Coop. 2018, 127, 45-69. [CrossRef]

80. Bretos, I.; Morandeira, J. La Economía Social ante la actual Crisis Económica en la Comunidad Autónoma del País Vasco. REVESCO Rev. Estud. Coop. 2016, 122, 7-33.

(C) 2020 by the authors. Licensee MDPI, Basel, Switzerland. This article is an open access article distributed under the terms and conditions of the Creative Commons Attribution (CC BY) license (http://creativecommons.org/licenses/by/4.0/). 